\title{
未加硫配合物 の貯蔵安定性†
}

(昭 和 33 年 5 月 9 日 受 理)

\section{立道 秀 麿・鈴木 重 成*}

アクリルゴムの未加硫配合物を, 詝蔵して, 放置日数とともに変化する加硫後の物理的性質について, 配合物の組成, 眝蔵温度, 貯蔵雾囲気等の影響を検討した。

\section{緒咅}

生ゴムに, 種々の配合剤を混練して, 眝蔵する場合に, 加硫剤 を含を全配合物と, カーボンのような補強剤のみを混合した場合 とがあるが，実際に加工する場合には，数日間，あるいは数週間 る貯蔵することがある。この時に配合物の加工性すなわち可塑性 が変化することが大きな障害であって，天然ゴム，ニトリルゴム， GR-S 等の一般合成ゴムで認められ，各種ゴムの種類めるいは配 合条件によって，安定性が異なると云われている1。このため に，実際には再ミキシングによって，可塑性をもどして，加工す る方法が，とられている。これは，主として放置中によるポリマ ーとカーボンの結合によるゲル（バウンドラバー）等の生成に起 因するるのと云われている。

アクリル系ゴムでは, 貯蔵によって, カーボンゲルの生成も認 められているが6), むしろ加硫後の物理的性質につよく影響し, 貯蔵期間が長くなると抗張力, モジュラス, 硬度を低下し, 伸び を増加することが認められている2)。この原因については，明ら かでなく，ポリマーとカーボンの相互作用のみならず，他の因子 も考学られるので, 本報告では, 種々の配合条件, 貯蔵条件が加 硫物に及ぼす影響を検討し，加硫方法の一指針を与えようとした ものである。

\section{実 験 方 法}

\section{生コムムおよび試剤}

試験したゴムは，精製したアクリル酸ブチルおよびアクリロニ トリルを, 87/13 の割合で, チオ硫酸ソーダ, 過硫酸アンモンを 用いて $40^{\circ} \mathrm{C}$ で乳化共重合し, 常法により塩析, 水洗, 乾燥 $\left(80^{\circ} \mathrm{C}\right)$ したものを使用した。不溶性ゲルは $1 \%$ 以下であった。配合試 薬は，試楽 1 級あるいは市販ゴム薬品を使用したが，アミンは， 窒素分析して純分換算して配合した。カーボンは HAF, Vulcan3 を使用した。

\section{加 硫 方 法}

素練りを行わずに，実験用ロールで，30〜 50C の温度で混練 した。混練後の配合物は, 厚さ $2 \sim 3 \mathrm{~mm}$ のシートにして貯蔵し た。種々の貯蔵条件のうち, 湿度については, 特に規定しなかっ たが，関係湿度 40〜60\% であった。一定日数放置後，シートを そのまま, $150^{\circ} \mathrm{C}, 1$ 時間加圧成型した。

\section{ムーニスコーチおよび加硫時間の測定}

初期の加硫速度は, Garvey の方法に準じて，ムーニ粘度計に

† 本研究を「アクリルコムに関する研究（第 3 報)」とする. 第 2 報は立道，鈴木，工化 $60 ， 224$ (1957).

* 東亜合成化学工業株式会社研究所：名古屋市港区昭和町.

1) C.H. Schroeder, Rubber Chem. Tech. 25, 651(1952).

2) J.E.Hansen, W.E.Palm, Rubber Age 75, 677 (1954).
よるスコーチ，加硫時間（あるいはキュア時間）をるって表示し $た^{3,4)}$ 。所定の温度で，配合物のムーニ粘度と時間 (min) の関係 曲線を求め, ムーニ粘度の最低の齐みを $m$ とすると, スコーチ 時間は $m+5$, キュア時間は $m+35$ のムーニ粘度に達するまで の時間とし, 真の加硫時間は, キュア時間とスコーチ時間の差と してあらわした。この実験では, $150^{\circ} \mathrm{C} て ゙ \mathrm{ML}$ ローター（大）を 使用して測定した。

\section{実験結果および考察}

\section{1）架橋剤の種類の影響}

アクリル系合成ゴムの架橋は, 主としてアミン類によってなさ れるが5)，まず 3 種類のアミンとイオウとを配合した未加硫配 合 物を常温で放置し，放置日数と加硫後の物理的性質について，約 1 カ月間, その変化を追跡した。配合条件执よび混練直後（2〜 3 時間）の加硫物の性質は，第 1 表に示した。第 1 表の值を 100 として, 所定の日数後に加硫した数值を百分率で示すと，第 1 3 図のような結果となった。

\section{第 1 表 配合条件拉よび加硫物の性質}

\begin{tabular}{|c|c|c|c|c|}
\hline & ゴ ム & 100 (部) & 100 & 100 \\
\hline & ステアリン酸 & 1.0 & 1.0 & 1.0 \\
\hline & 1オウ & 0.5 & 0.5 & 0.5 \\
\hline 合組成 & カーボンブラック (HAF) & 50 & 50 & 50 \\
\hline & トリエチレンテトラミン & 1.0 & - & - \\
\hline & トリメンベース & - & 2.0 & - \\
\hline & ジェチレントリアミン & - & - & 1.0 \\
\hline & 抗㖘力 $\left(\mathrm{kg} / \mathrm{cm}^{2}\right)$ & 135 & 140 & 146 \\
\hline & 最大伸度（\%） & 470 & 470 & 490 \\
\hline & 300\% モジュラス & 71 & 75 & 88 \\
\hline & 硬 度 (Shore & 62 & 61 & 61 \\
\hline
\end{tabular}

第 1 図 TETA 配合の眝蔵安定性 (常温)

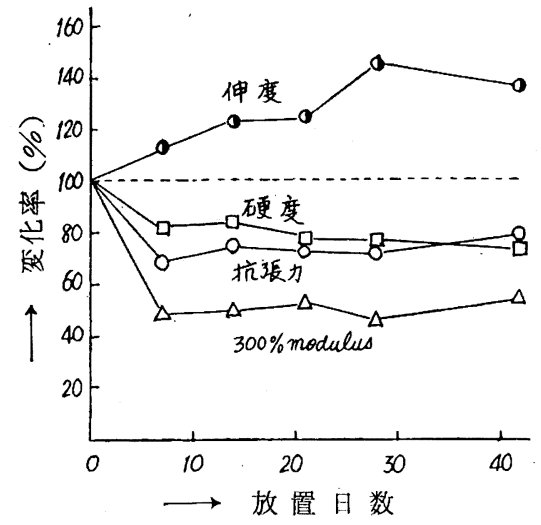

ぞのアミンを配合し ても，放置日数ととも に, 抗張力, 硬度, モ ジュラスが低下し，伸 びが增加する傾向が認 められた。特に, 伸び とモジュラスの変化は 著しく, 40～50\%にも 達した。トリエチレン テトラミン (TETA), ジェチレントリアミン を配合したものは，最 初の 1 週間までの少化 が大きく，その後の変化は少なかった。トリメンベースは，䄪 1

3) B.S. Garvey, Jr., D. W. Yockum, Rubber Chem. Tech. 26, 919 (1953).

4) ASTM, D 1077-49 T.

5）鈴木, 立道, 工化 59, 1082 (1956).

6) 立道, 鈴木, 工化 61，1521 (1958). 
第 2 威 TB 配合の眝藏安定性(常温)

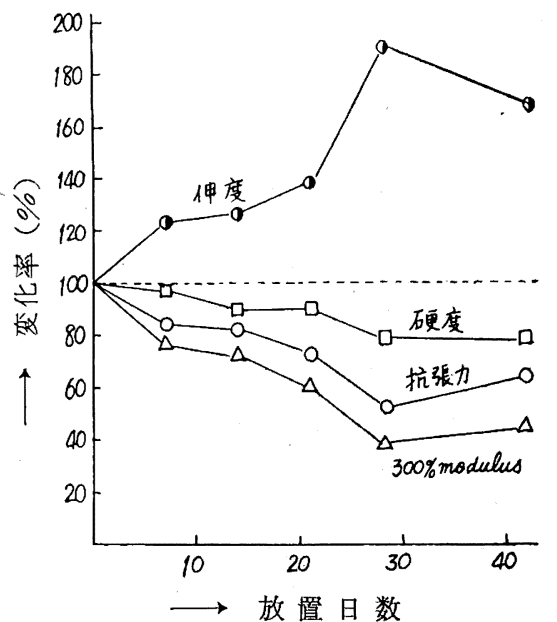

第 3 図 DETA 配合の睁藏安定性（常温）

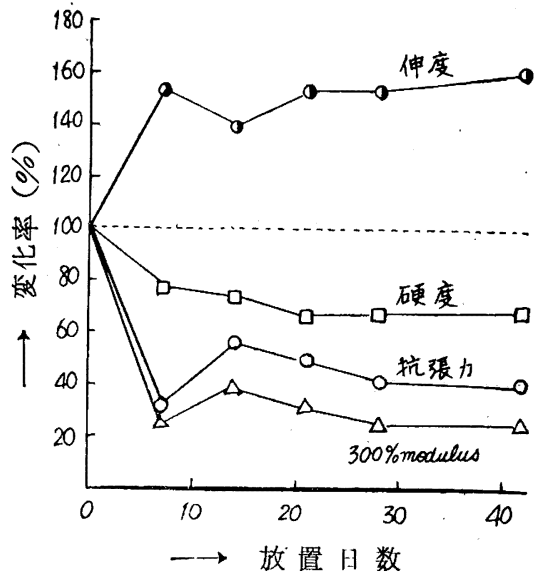

カ月まで徐々に変化 した。この物理的性 質の変化は, 貯蔵し た配合物を，再ミキ シングして加硫して も防止出来ず，放置 中にイオウ，アミン 等の加硫剤がブルー ムするためとは考光 られない。

2）配合剤の相互 作用

未加硫配合物を貯 蔵して, 加硫物の性 質が変化する因子と して考えられること は，カーボンとポリ マ一間の相互作用, あるいは加硫阏の変 質等である。この二 つの因子を，切りは なして観察するため にゴムとカーボン, ゴムと加硫剤 ( $\mathrm{TE}$ TA とイオウ) のみ を予め混練して，常 温で放置し, 所定の 日数後に残りの配合 凰を混練して直ちにキュアした。合計した配合組成は，生ゴム 100 部, ステアリン酸（カーボンと同時に混練）1 部, TETA 1 部，イオウ 0.5 部で, $150^{\circ} \mathrm{C}$ で 1 時間キュアした。

ゴムとカーボンのみを混練し，加硫剤をキュア直前に加えた場 合, 加硫物の機械的性質は第 4 図のよ5になった。伸び，抗張力 が増加し, 硬度, モジュラスが低下した。ポリマーとカーボンブ ラックゲルの生成することを考劣ると，一般に，伸びが低下し， 抗張力，モジュラス等は增加するが，第 4 図ではむしろ逆になっ ている。これは, カーボンゲルが, 後で添加した加硫剤の分散

第 4 図ゴムとカーボン配合物の 貯蔵安定性

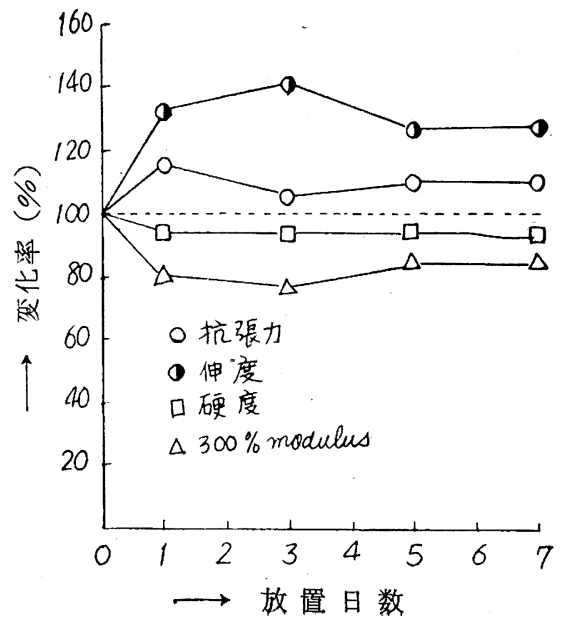

を、さまたげるため ではないかと思われ る。別に生ゴムのみ を，前と同一条件で 放置して，カーボ ン, 加硫剤を後添加 すると，第 5 図のよ 万に，加硫物の性質 はほとんど変動しな かったので，第 4 㘠 から、ゴムとカーボ ンとの間に相互作用 のあることは明らか である。

次に，ゴムと加硫
第 5 図ゴムの貯蔵安定性

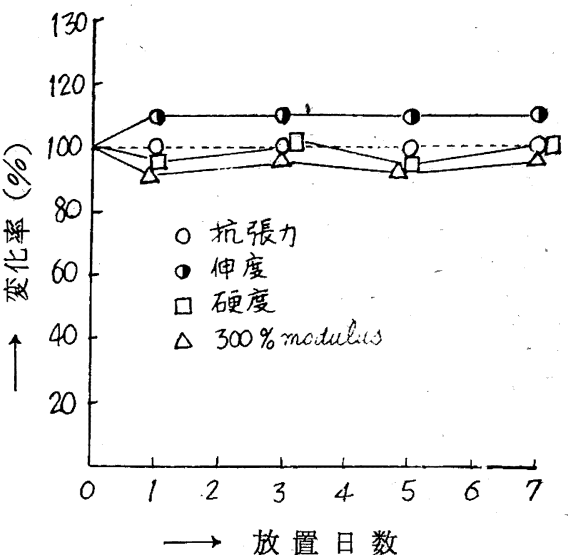

第 6 図、ゴムと加硫剤配合物の眝蔵安定性

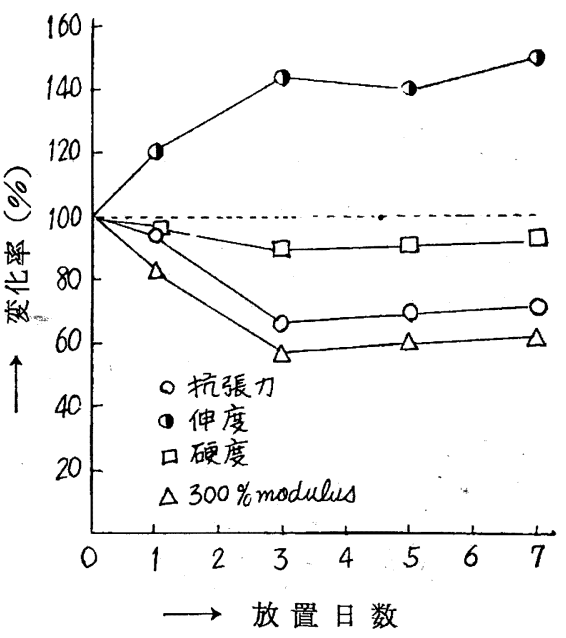

剂のみを予め混練し て眝蔵した場合は, 第 6 図のよ5飞，最 も変化が大きく，モ ジュラス, 抗張力が 60〜70\%まで低下 し，伸びが 150\% K あ増大した。あたか も, 加硫不足の傾向 を示した。

以上 1 週間の経過 からみて, 䝪蔵中に, 加硫物の性質を劣化 させる最子大きな因 子は，ポリマーと加 硫剤との相互作用て ありカーボンの存在 は，モジュラスを低 下させるが，抗張力 は，むしろ 10\% 程 度増加させ，前者に くらべ影響は少ない あのと思われる。

3）空気酸化の影

配合物が貯蔵中に 変質するのが，主と 乙て加硫剤中のアミ ンの空気酸化によるものとすれば，放置条件によって影響される 筈である。そこで第 1 表の TETA を配合した配合例について, 1 週間の貯蔵安定性を, 種々の条件で検討した。

$40^{\circ} \mathrm{C}$ の恒温槽中に, $\mathrm{CO}_{2}, \mathrm{~N}_{2}$, 空気等で十分置換したフラスコ を設置し，その中に未加硫配合シートを入れて，所定の日数ごと に取出してキュアした。

空気， $\mathrm{N}_{2}, \mathrm{CO}_{2}$ 中に 1 週間放置して得た結果を，それぞれ第 $7 \sim 9$ 図に示した。

1 週間程度の比較的短い眝蔵期間空気中に放置した場合は，前 に示した長期間（第 1 図）の場合とは異なった傾向が認められ た。

第 7 図 空気中における眝蔵安定性 抗張力についてみる $\left(40^{\circ} \mathrm{C}\right)$

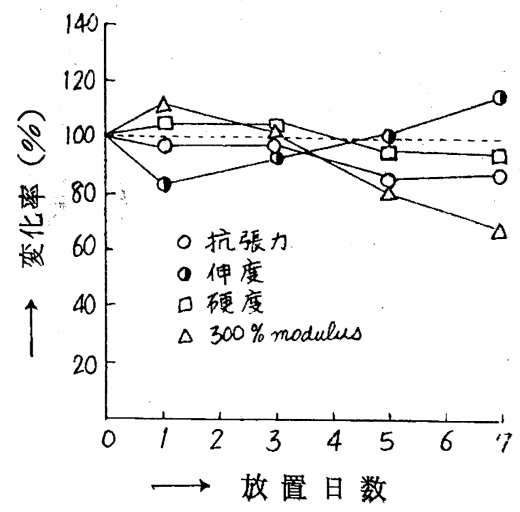
と，最初の数日間は，ほ とんど低下せず，以後放 置日数が長くなるにつれ て低下した。モジュラ ス, 硬度抗掁力と同じ 経過をたどり，伸びは初 期ではむしろ低下し，次 第に增大した。

$\mathrm{N}_{2}$ 中に放置すると， 抗張力は最初に増加し, 以後やや低下するが, 硬 
第 8 図窒素中に和ける貯蔵安定性

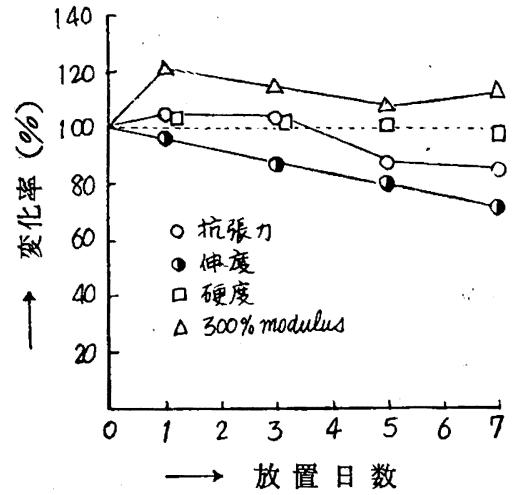

第 9 図炭酸ガス中に扣ける眝蔵安定性 $\left(40^{\circ} \mathrm{C}\right)$

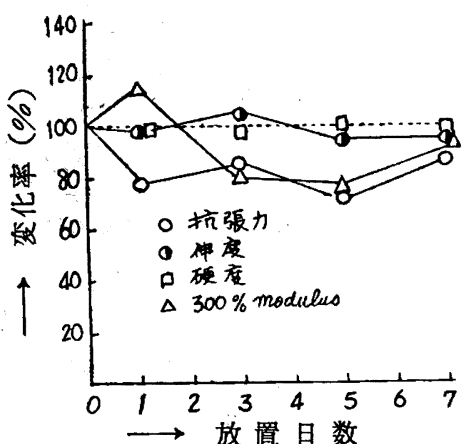
$\left(40^{\circ} \mathrm{C}\right)$

度，モジュラスは空気 の場合のよ5に低下せ ず，伸びる最初から低 下した。モジュラスか らみて, 空気中ではい ったん架橋度が增大す るが，次第に低下する 傾向にあり， $\mathrm{N}_{2}$ 中で は，この傾向が少なか った。低下するのは, 主としてアミンの酸化 による影響で，增加す るのは, カーボンとポ リマー間に生成するゲ ル（パウンドラパー） の効果と思われる。

$\mathrm{CO}_{2}$ の中では，第 9 図のように，硬度，伸 びの変化は少ないが抗 張力, モジュラスが低 下した。アミンは $\mathrm{CO}_{2}$ を吸収し，炭酸塩を形 成するものと思われ， キュアの温度で, 再び

$\mathrm{CO}_{2}$ を放出して加硫シートの表面に気泡を生じ，架橋効果も妨害 される傾向を示した。

眝蔵中の温度は, アミンの酸化速度に影響を与えるものと思わ れるので, $70^{\circ} \mathrm{C}$ で前と同じょうにして，空気と $\mathrm{N}_{2}$ との場合を 比較すると，第 $10 ， 11$ 図のよ5になった。抗張力は, $\mathrm{N}_{2}$ の中 では増加するが，空気中で はほとんど変化せず，伸度 第 10 図空気中に拈ける 眝藏安定性 $\left(70^{\circ} \mathrm{C}\right)$

は最初增加し漸次低下する 傾向にあり，モジュラスは 極小值が初期にあり， $\mathrm{N}_{2}$ 中の方が，増加の傾向が大 であった。

モジュラスの傾向からみ $\tau, 40^{\circ} \mathrm{C}$ の場合とちょう ど逆になったが放置温度が 高くなると，酸化によるア ミンの劣化よりも，むしろ

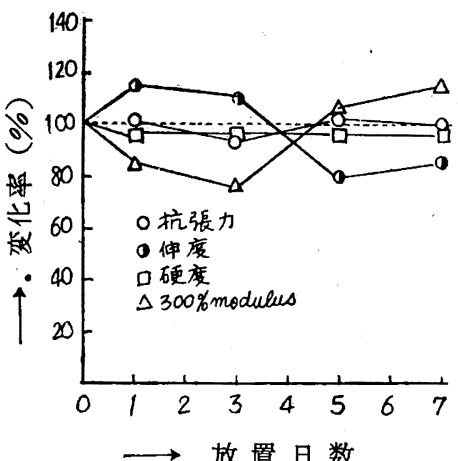
バウンドラバーの生成と, ある程度のスコーチの方が強く影響し たものと思われる。特に $\mathrm{N}_{2}$ 中では, この傾向が著しく認めら れた。

眝蔵中に起るアミンの酸化，バウンドラバーの生成6) 等につい ては，直接定量にまたねば明らかに出来ないが，以上の加硫物の 性質の変化の状態からみると，定性的に加硫剤として配合したア
第 11 図窒素中に拈ける眝蔵安 定性 $\left(70^{\circ} \mathrm{C}\right)$

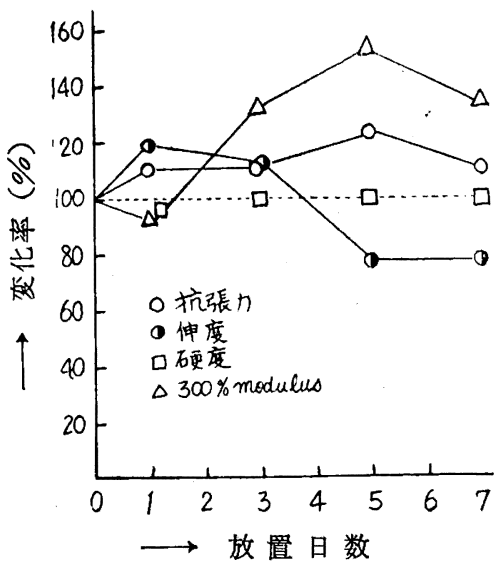

ミンは，酸化によってそ の効果を次第に減少し， 眝蔵期間が比較的短い 時，あるいは高温で貯蔵 した時には，配合物中の バウンドラバーの生成の 影響がつよくあらわれ， 両者の効果が重なり合っ て，諸性質に極大あるい は極小值が認められ，複 雑な挙動を示したものと 思われる。

4）加硫速度に及ぼす 影響

アミンが，空気酸化されると，加硫不足の状態を示したが，ム 一ニ粘度計で，初期加硫速度に及ぼす程度を，スコーチ， キュ ア，加硫時間で比較した。配合は第 1 図と同じ配合組成を，常温 で約 1 カ月貯蔵し，所定の日数でムーニ粘度曲線を求めた。 150 ${ }^{\circ} \mathrm{C}$ のスコーチ，キュア，加硫時間を，放置日数に対してプロッ トすると，第 12 図のような結果となった。

スコーチ時間は, 2 週間まで大きな変 第 12 図加硫速度に及ぼす貯蔵日数 化はなかったが， 3 週間以後になると急 激に遅くなり, 加硫 時間(あるいはキュ ア時間）は最初から 放置日数に比例して 増加し, 加硫速度が 放置日数によって著 しく遅くなることが 明瞭となった。初期 加硫速度の低下は, 架橋効果の消失を意 味し, この結果一定 条件でキュアした加 硫物の抗張力, モジ ュラス，硬度を低下 （常温）

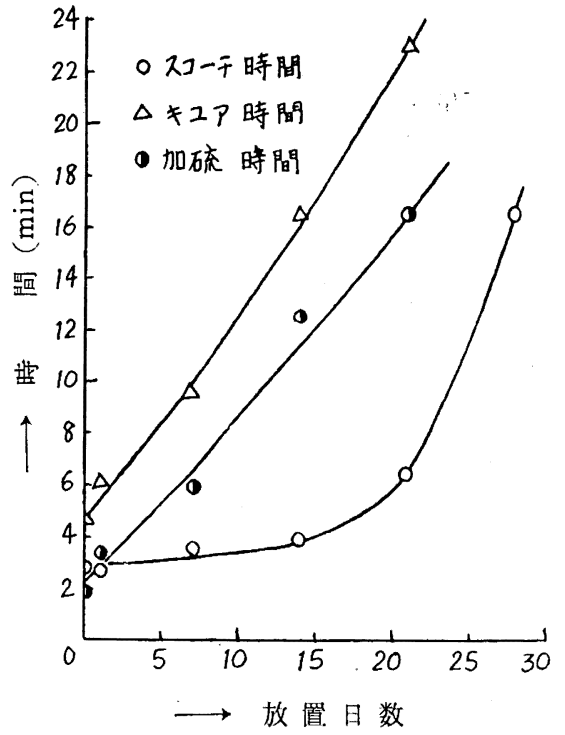

架橋剤として使用するアミンは，酸化され易いものであるが， 比較的安定といわれているトリメンベースでも，同じよ5に劣化 が起り，配合物中ではアミンのみを空気中に放置した場合より も，予想以上に不安定になるものと思われる。したがって実際の 加工に際してはアミンを配合してからは少なくとも 1 冝夜以内に キュアすることが肝要である。

終りに発表を許可された東亜合成化学工業株式会社ならびに大 橋研究所長に深謝いたします。 